\title{
Conditional Objectives of Conspiracies
}

More than any other offense, the crime of conspiracy departs from the traditional act requirement for criminal prosecution. ${ }^{1}$ Focusing on shared design rather than concerted action, the function of conspiracy law is not to punish offenders for what they do, but for what they agree to do. ${ }^{2}$ Because future circumstances inevitably influence the acts or consequences $^{3}$ that follow from an agreement, determining a conspiracy's punishable object ${ }^{4}$ is inherently speculative. Being forward-looking, all conspiratorial objects are, to some extent, variable ${ }^{5}$ or tentative. ${ }^{6}$

No legal guidelines exist for determining which conditional objectives justify prosecution at the early stage authorized by conspiracy law. Consequently, confusion in determining a conspiracy's punishable object has deepened the uncertainty that generally plagues the crime's enforcement. ${ }^{7}$

1. See Goldstein, Conspiracy to Defraud the United States, 68 YALE L.J. 405, 406 (1959) (discussing conspiracy's impingement of the act requirement).

2. See, e.g., Pereira v. United States, 347 U.S. 1, 11 (1954) (commission of substantive offense and conspiracy to commit it are distinct crimes; essence of conspiracy offense is agreement); United States v. Nims, 524 F.2d 123, 126 (5th Cir. 1976) ("The essence of the crime of conspiracy is the agreement rather than the commission of the objective substantive crime."), cert. denied, 426 U.S. 934 (1976); see also P. Marcus, Prosecutton and DefEnSE of Griminal Conspiracy Cases $\$ 2.02$ at 2-2 (1983) ("The crime of conspiracy is the illegitimate agreement, and the agreement is the crime.").

3. Previous analyses of the object scope of conspiracies have treated inconsistently the direct criminal actions and the indirect criminal consequences resulting from a conspiratorial agreement. The Model Penal Code, for example, has defined the punishable scope of conspiracies to include conditional actions but not conditional consequences. See infra p. 903.

This inconsistent treatment, however, is contrary to the principles underlying conspiracy law, which seek to prevent socially harmful results and to apprehend those who have revealed a dangerous likelihood of causing such results, whether directly or indirectly. The determination of an agreement's substantive criminal object, therefore, should address the illegal actions and the illegal consequences of a conspiracy in a consistent way.

4. The crime of conspiracy requires an agreement to commit a specific criminal object. See, e.g., United States v. Rosenblatt, 554 F.2d 36, 38-39 (2nd Cir. 1977) (conspiracy law requires agreement concerning object of conspiracy; "it is clear that a general agreement to engage in unspecified criminal conduct is insufficient"); United States v. Gallishaw, 428 F.2d 760, 763 (2nd Cir. 1970) (general agreement that machine gun rented to co-conspirator would be used "to do something wrong" insufficient to support conviction for conspiring to rob bank).

5. Objectives are variable when the criminal consequences of their fulfillment will change in the face of differing circumstances. A plan to burn down a building, for instance, might have the effect either of destroying property or of destroying life, depending on the occupancy of the building.

6. Objectives are tentative when their execution depends upon future circumstances, as when would-be burglars condition their substantive object of transporting stolen goods across state lines on the successful completion of their planned burglary.

7. See, e.g., Krulewitch v. United States 336 U.S. 440, 449 (1949) (Jackson, J., concurring) ("[T]he looseness and pliability of the [conspiracy] doctrine present inherent dangers which should be in the background of judicial thought wherever it is sought to extend the doctrine to meet the exigencies of a particular case."); of. Developments in the Law-Criminal Conspiracy, 72 Harv. L. REv. 920, 922 (1959) (flexibility and formlessness of conspiracy law have evoked widespread criticism from judicial and academic commentators) [hereinafter cited as Developments]. 
There are compelling reasons for adopting a legal rule clearly delineating the scope of punishable conspiratorial objectives. The liberty interest that prohibits punishing intent unless it is "objectively manifested by action resulting or likely to result in socially harmful consequences"8 requires the state to isolate those conspiratorial intentions that present a genuine social threat. Moreover, the avoidance of arbitrary or discriminatory enforcement demands a uniform means of determining which types of objectives should define an agreement as criminal. ${ }^{8}$

It is the purpose of this Note to define the objectives of criminal conspiracies in a way that is both uniformly enforceable and consistent with the limited and justifiable goals of conspiracy law: preventing likely crimes and apprehending likely criminals.

\section{Conspiracy and Griminal Law}

\section{A. The Act Requirement}

Criminal law is primarily concerned with substantive behavior. The need to safeguard individual freedom constrains the state from arresting and punishing anyone until he or she has manifested anti-social intentions through harmful acts. ${ }^{10}$ This requirement of an act is premised on a realization of the difficulties of reading another person's mind, distinguishing between idle speculations and serious plans, and predicting which of even serious plans will ever be manifested in socially harmful conduct. ${ }^{11}$

The act requirement, therefore, attempts to guarantee that criminal sanctions will be imposed only on those who actually threaten society. Moreover, it reserves the extreme recourse of state action as a last resort, to be used only after moral deterrence or the threat of sanctions clearly

8. Developments, supra note 7 , at 922 .

9. Due process demands that criminal statutes and common-law crimes be reasonably precise in defining the conduct which lies within their scope, so as not to provide an easy means of discriminatory enforcement by prosecuting officials. Papachristou v. City of Jacksonville, 405 U.S. 156, 170 (1972) (holding unconstitutional a vagrancy statute because inadequate standards "permit and encourage an arbitrary and discriminatory enforcement of the law."); Thornhill v. Alabama, 310 U.S. 88, 97-98 (1940) (striking down penal statute "which readily lends itself to harsh and discriminatory enforcement by local prosecuting officials, against particular groups"). Moreover, criminal laws violate due process if they are so vague that they fail to provide judges and juries with legally fixed guidelines defining prohibited conduct. See Giaccio v. Pennsylvania, 382 U.S. 399, 402-403 (1966).

For a discussion of the due process concerns with the enforcement of potentially vague criminal laws, see W. LaFave \& A. ScotT, Criminat Law 87-88 (1972).

10. For a historical discussion of the place of the act requirement in Anglo-American law locating the doctrine at least as early as the sixteenth century, see Hitchler, The Physical Element of Crime, 39 Dick. L. REv. 95, 96 (1934).

11. See Goldstein, supra note 1 , at 405 ; see also 4 W. Blackstone, Commentaries *20 ("[A]s no temporal tribunal can search the heart or fathom the intentions of the mind, otherwise than as they are demonstrated by outward actions, it therefore cannot punish for what it cannot know."). 
has failed. At the same time, it provides a discrete focus for criminal prosecutions so that multiple actions and punishments can be avoided. ${ }^{12}$

\section{B. The Exception of Conspiracy}

Mens rea is usually considered in criminal law only as it is needed to establish accountability for substantive behavior. ${ }^{13}$ State of mind, however, is the primary concern of conspiracy law. ${ }^{14}$ For purposes of a conspiracy prosecution a defendant's criminal liability is not based on his substantive crimes, but on "the fair import of the concerted purpose or agreement as he understands it." 10

The state is authorized to move against conspirators before they have committed any substantive acts harmful to society-sometimes before they have even come close to committing any such acts. ${ }^{16}$ One justification for this drastic step stems from the danger created by conspiracies that the agreed-upon objectives will ultimately be carried out. ${ }^{17}$ By transforming individual purpose into group enterprise, conspiracies increase this likelihood in a number of ways. Conspiracies direct added resources toward the

12. See Goldstein, supra note 1, at 405-06.

13. See Harno, Intent in Criminal Conspiracy, 89 U. PA. L. REv. 624, 635 (1941) (in majority of crimes law is most concerned with act; intent must be established to hold accused responsible for act).

14. The crime of conspiracy-as defined under the federal law-does have non-mental elements. The offense requires both an act of agreement and an overt act in furtherence of the conspiracy. 18 U.S.C. $\$ 371$ (1982) (a crime if "two or more persons conspire . . . to commit any offense against the United States ... . and one or more of such persons do any act to effect the object of the conspiracy"); see also United States v. Avila-Dominguez, 610 F.2d 1266 (5th Cir. 1980) ("The essential elements of criminal conspiracy are an agreement between two or more persons to commit a crime and an overt act in furtherance of the agreement by one of the conspirators."), cert. denied, 449 U.S. 887 (1980).

These requirements, however, are of a different kind and serve a different purpose than the traditional actus reus. Unlike most criminal actions, the act of agreement is harmless in and of itself. Similarly, a harmless action may constitute an overt act for purposes of the conspiracy law. See United States v. Eucker, 532 F.2d 249, 254 (2d Cir. 1976) (silence may be sufficient overt act if intended to facilitate conspiracy), cert. denied, 429 U.S. 822 (1976).

The act of agreement and the overt act requirements both are significant for what they reveal about the conspirators' states of mind. The execution of these acts in furtherance of the conspirators' intentions is important because it indicates that these intentions have crossed a significant threshold of seriousness, and hence of dangerousness. See MODEL PENAL CoDE $\$ 5.03$ comment at 97 (Tent. Draft No. 10, 1960) (act of agreeing with another significant because it indicates that clear threshold of expectation of committing object crime has been crossed). But see infra p. 906 (agreements do not always indicate that such a threshold has been crossed).

15. United States v. Peoni, 100 F.2d 401, 403 (2d Cir. 1938).

16. Sayre, Criminal Conspiracy, 35 HaRv. L. REv. 393, 399 (1922) ("One may become guilty of conspiracy long before his act has come so dangerously near to completion as to make him criminally liable for the attempted crime.").

17. Callanan v. United States, 364 U.S. 587, 593 (1961) (concerted action increases likelihood that criminal object will succeed). 
fulfillment of a substantive criminal object. ${ }^{18}$ Conspiracies facilitate division of labor among the members of the group. ${ }^{19}$ Moreover, the psychological reinforcement which the conspirators exercise over each other diminishes the chances that the enterprise will be abandoned short of fulfillment. ${ }^{20}$

A second justification exists for abrogating the act requirement in prosecuting conspiracies. ${ }^{21}$ By acting on their intentions even to the limited extent of reaching an agreement, conspirators have shown a clear intention of committing a specific type of crime, not only on this occasion, but in the future as well. ${ }^{22}$ Even if frustrated in their specific contemplated crime, conspirators present a continuing threat to society that they will ultimately execute their criminal aims unless prevented by the law. By unambiguously committing themselves to the execution of a specific crime, ${ }^{23}$ therefore, conspirators mark themselves as dangerously likely criminals and as proper targets for state action. ${ }^{24}$ Thus, the safeguards of the act requirement against premature or unnecessary criminal enforcement should not prevent the apprehension of conspirators whose own actions have revealed a clear expectation of committing a specific crime.

18. See Comment, Criminal Conspiracy: A Balance Between the Protection of Society and the Rights of the Individual, 16 ST. LourS U.L.J. 254, 260 (1971).

19. See United States v. Spock, 416 F.2d 165, 184 (1st Cir. 1969) (Coffin, J., dissenting in part); Marcus, Federal Conspiracy and Complicity Statutes-Panel Discussion, in Criminal. Law aND THE Corporate CounSEl 182 (A. Abramovsky ed. 1981) [hereinafter cited as Abramovsky].

20. See Morton, Conspiracy as a Military Offense, J.A.G. Journal, Aug. 1964, at 309, 310. Professor Goldstein argues, however, that the psychology of conspiracy is more complex:

More likely, empirical investigation would disclose that there is as much reason to believe that a large number of participants will increase the prospect that the plan will be leaked as that it will be kept secret; or that the persons involved will share their uncertainties and dissuade each other as that each will stiffen the others' determination.

Goldstein, supra note 1, at 414.

21. See Model Penal Code $\$ 5.03$ comment at 97 (Tent. Draft No. 10, 1960) ("In the course of preparation to commit a crime, the act of combining with another is significant both psychologically and practically, the former since it crosses a clear threshold in arousing expectations the latter since it increases the likelihood that the offense will be committed.") (footnote omitted).

22. According to the Model Penal Code, one justification for punishing conspiracies and attempts is that:

[C]onduct designed to cause or culminate in the commission of a crime obviously yields an indication that the actor is disposed towards such activity, not alone on this occasion but on others. There is a need, therefore . . . for a legal basis upon which the special danger that such individuals present may be assessed and dealt with. They must be made amenable to the corrective process that the law provides.

Model Penal. Code $\S 5.01$ comment at 25 (Tent. Draft No. 10, 1960).

23. See Developments, supra note 7 , at 924 (act of agreeing "provides a substantially unambiguous manifestation of intent").

24. See, e.g., State v. Saint Christopher, 305 Minn. 226, 233-34, 232 N.W.2d 798, 803 (1975) (endorsing Model Penal Code position that major basis of conspiratorial liability is unequivocal evidence of firm purpose to commit crime). 


\section{The Inadequacy of Federal Conspiracy Law}

\section{A. The Limits of Intuition}

As projections into the future, conspiratorial intentions, and the objects they define, are by nature conditional. ${ }^{25}$ It is intuitively clear, however, that not all such objects are justifiable grounds for criminal liability. On one hand, radical separatists who declare their independence from the United States and agree to use automatic weapons to defend their proclaimed capitol against all invaders, for instance, are properly charged with conspiring to assault federal agents, despite their lack of certainty that such agents would "come in conflict with [their] essentially defensive precautions." ${ }^{28}$ On the other hand, would-be holdup men should not be chargeable with conspiring to murder simply because their intended plan might cause the heart attack of a particularly vulnerable clerk. ${ }^{27} \mathrm{~A}$ strict liability standard of conspiracy law of this kind would transform an agreement to do something into an agreement to do virtually anything.

In many cases, however, it is less intuitively easy to define the proper limits of a conspiracy. Does a conspiracy to swindle prospective drug buyers by selling them powdered sugar encompass the substantive object of assaulting the buyers because they may discover the fraud and resist the swindlers ${ }^{28}$ Is an agreement to lie about a gathering of alleged gangsters a conspiracy to commit perjury because a grand jury investigation might require the conspirators to testify about the meeting under oath ?29 $^{29}$

Complications in determining a conspiracy's scope must arise when, as typically happens, "under one or more scenarios the plan will not require a crime. . [ [o]r will not require a federal crime . . [ [o]r will require a lesser crime than another contingency ..."30 The federal law, however, provides no rule for determining which of the various conditional objects of a conspiracy should determine the legal status of the agreement. ${ }^{31}$

25. The substantive objects of a conspiracy are conditional both in the sense that circumstances will affect whether the object is executed at all and in the sense that circumstances will affect the criminal consequences of the actions that do take place.

26. United States v. James, 528 F.2d 999, 1009 (5th Cir. 1976), cert. denied, 429 U.S. 959 (1976).

27. Cf. People v. Stamp, 2 Cal. App. 3d 203, 210, 82 Cal. Rptr. 598, 603 (Cal. Ct. App. 1969) (holdup men guilty of murder under felony murder rule when victim subsequently died of heart attack, because felony murder is strict liability offense), cert. denied, 400 U.S. 819 (1970).

28. United States v. Feola, 420 U.S. 671 (1975).

29. United States v. Bufalino, 285 F.2d 408 (2d Cir. 1960).

30. Duke, Conspiracy, Complicity, Corporations, and Federal Code Reform, in Abramovsky, supra note 19 , at 153 .

31. The government has been free to rely on hindsight to determine which of the possible unfoldings of a plan should be chosen as its object. See, e.g., United States v. Clay, 495 F.2d 700 (7th Cir. 1974) (affirming conviction for conspiring to attempt to enter a savings and loan), cert. denied, 419 U.S. 937 (1974); United States v. Etheridge, 424 F.2d 951 (6th Cir. 1970) (affirming conviction for conspiring to murder informant based on agreement to rob banks), cert. denied, 400 U.S. 993 (1971). 


\section{B. The Limits of the Federal Law}

United States $v$. Feola ${ }^{32}$ best exemplifies the current state of the federal law governing conspiratorial objectives. In Feola the Supreme Court upheld a conviction for conspiring to assault federal agents. The proof in the case, however, consisted only of a showing that the defendants had attempted to swindle agents, whom they mistook for drug buyers, by offering them sugar disguised as heroin. When the sale broke down, the defendants assaulted the buyers, were in turn overcome by them and arrested as the "buyers" revealed themselves as undercover narcotics officers..$^{33}$

From these facts the government inferred a conspiracy to assault the agents. ${ }^{34}$ No proof was offered that such an assault was a likely event at the time of the agreement. ${ }^{35}$ Nor was there proof that the swindlers anticipated assaulting anyone. In fact, the efforts of the defendants to guarantee that the swindle would work indicate that they fully believed that their ruse would be successful. The federal conspiracy law thus sanctions the punishment of individuals for conspiring to an act that they never anticipated committing.

32. 420 U.S. 671 (1975).

33. No other evidence of the conspirators' objectives was offered to support the conviction for conspiracy to assault federal officers. See United States v. Alsondo, 486 F.2d 1339, 1342 (2d. Cir. 1973), rev'd sub nom. United States v. Feola, 470 U.S. 671 (1975). The Supreme Court specifically held that this evidence showed a conspiracy to assault the drug buyers should the sellers' ruse fail. 470 U.S. at 674 .

34. United States v. Alsondo, 486 F.2d 1339, 1342 (2d Cir. 1973) (setting forth government's case), rev'd sub nom. United States v. Feola, 420 U.S. 671 (1975).

35. Because conspiracy is a continuing offense, the government can claim that conspirators reformed the object of their agreement in the face of altered circumstances. The state can thus suggest that any consummated crime was properly within the scope of a conspiracy because the conspiracy's object was reformed an instant before the substantive crime was committed. This perception of the fluidity of conspiratorial agreements is one of the reasons why problems related to conditional objects are rarely raised in conspiracy prosecutions, despite their routine occurrence. $C f$. Duke, supra note 30 , at 173 n.39 (federal jurisdiction exists even when federal crime is only tentatively contemplated at time of intial agreement because "[c]onspirators . . . may subtly alter their 'meeting of the minds' as circumstances change").

The assumption that an agreement is reformed in response to unfolding circumstances, however, is unwarranted absent proof that a subsequent act of agreement took place. Government reliance on the unproven assumption that acts of conspirators are preceeded by a reformulation of an agreement's object has been expressly rejected by the Supreme Court. See Grunewald v. United States, 353 U.S. 391,404 (1957) (acts of concealment may not be used as circumstantial evidence from which to infer an actual agreement to conceal in the absence of "direct evidence in this record to show anything like an express . . . agreement among the conspirators to continue to act in concert in order to cover up, for their own self-protection, traces of the crime after its commission."). The Third Circuit stressed the importance of requiring proof of an act of agreement in United States v. Kates:

It is well established that the 'gist' of a conspiracy is an agreement. However slight or circum.

stantial the evidence may be, it must, in order to be sufficient to warrant affirmance, tend to prove that the appellant entered into some form of agreement, formal or informal, with his alleged co-conspirators.

508 F.2d 308, 310 (3rd Cir. 1975) (footnote omitted). Abandoning this requirement would render conspiracy nothing more than a device for groundlessly multiplying a defendant's exposure to trial and punishment for attempted or consummated group criminal conduct. 
The holding in United States $v$. Etheridge ${ }^{36}$ also illustrates the principle that a conspiracy's object encompasses all of the unexpected and undesired contingencies that might arise in the course of a failed criminal plan. ${ }^{37}$ The five defendants in Etheridge had formed a conspiracy to commit several bank robberies. When one of their co-conspirators began providing information to the F.B.I., two of the members of the group murdered him. The Sixth Circuit court conceeded that there was no proof that two of the remaining conspirators participated in, or even knew about, the murder of the informant. ${ }^{38}$ Nonetheless, the court affirmed the convictions of all five defendants for conspiring to commit murder ${ }^{39}$ on the grounds that:

there is ample evidence that they knowingly joined and participated in a conspiracy to commit armed robbery of banks. We conclude that the murder actually commited must be viewed as within the reasonable contemplation of those who formulated and participated in the bank robbery scheme and was in furtherance of the plan. ${ }^{40}$

The lack of principled limits on the punishable objectives of a conspiracy, ${ }^{41}$ therefore, makes it possible under the federal law to punish a conspiracy to rob banks as an agreement among the conspirators to murder each other.

36. 424 F.2d 951 (6th Cir. 1970), cert. denied, 400 U.S. 993 (1971).

37. This principle also underlies federal cases holding that an agreement to commit a substantive offense has a punishable object of attempting to commit the offense. See, e.g., United States v. Dearmore, 672 F.2d. 738 (9th Cir. 1982) (conspiracy to attempt to rob bank is indictable offense); United States v. Clay, 495 F.2d 700, 710 (7th Cir. 1974) (affirming conviction for conspiring to attempt to enter savings and loan with intent to rob it), cert. denied, 419 U.S. 937 (1974).

The courts are split on the question of whether failure is a required element of the crime of attempted bank robbery. Compare United States v. Malasanos, 472 F.2d 642 (7th Cir. 1973) (per curiam) (success of defendant in committing bank robbery is no defense to charge of attempted bank robbery under federal bank robbery statute 18 U.S.C. $\$ 2113(\mathrm{a})$ ) with United States v. Baker, 129 F. Supp. 684, 685 (S.D. Cal. 1955) (legal elements of attempt under 18 U.S.C. § 2113(a) include failure to consummate crime).

Conspiring to attempt makes sense under the theory of attempt advocated in Malasanos because, under such an interpretation of 18 U.S.C. $\$ 2113(\mathrm{a})$, any plan to succeed is inherently also a plan to attempt. A crime of conspiring to attempt is completely unjustifiable, though, when attempt demands failure. Such a crime would require conspirators to agree to fail in their criminal scheme. This scenario, however, seems to be the one envisioned in United States v. Clay, 495 F.2d at 710 ("While entering the savings and loan was obviously an objective of the conspiracy. - the men necessarily contemplated their attempting to gain entry into the building. ..."). But see United States v. Meacham, 626 F.2d 503, 509 n.7 (5th Cir. 1980) (criticizing Clay and noting that "it would be the height of absurdity" for conspirators to conspire to fail in their criminal plan).

38. United States v. Etheridge, 424 F.2d 951, 964 (6th Cir. 1970).

39. Count 1 of the indictment, under which each defendant was convicted, alleged "a conspiracy to rob federally insured banks with dangerous weapons and to commit murder to avoid apprehension for the same." Id. at 953.

40. Id. at 965 .

41. Some limitation on the government's power to expand the scope of conspiracies to include conditional objectives was imposed by the Supreme Court in the so-called concealment trilogy. See 
The majority of questionable rulings dealing with the object scope of conspiracies expand that scope beyond the dimensions necessary to prevent likely crimes or to apprehend conspirators who are dangerously resolved to commit an object crime. United States v. Bufalino, ${ }^{42}$ however, displays the potential of the courts to unduly restrict the object scope of a conspiracy in the absence of a guiding legal rule.

Bufalino and nineteen co-defendants were convicted of conspiring to commit perjury concerning a gathering of over fifty-eight alleged underworld figures ${ }^{43}$ which they attended. The Court of Appeals reversed the convictions, holding that, even if the government had proved an agreement to lie about the meeting, the government would also have had to prove that the defendants "knew or should have known that there would be [some] formal investigations under oath."

This stringency is contrary to the principles underlying conspiracy law. The facts produced by the government adequately demonstrated that a formal investigation of the gathering was likely and that the defendants must have believed that such an investigation was likely when they allegedly entered into their agreement to lie. ${ }^{45}$ Convicting the Bufalino defendants of conspiring to commit perjury, therefore, would have served both

Grunewald v. United States, 353 U.S. 391, 404 (1957) (rejecting government's argument that acts of concealment should be used as circumstantial evidence from which to infer that conspirators had made an agreement to conceal main conspiracy); Lutwak v. United States, 344 U.S. 604, 616-17 (1953) (rejecting as unproven government's contention that, as part of a conspiracy to defraud, conspirators agreed to conceal the fraud); Krulewitch v. United States, 336 U.S. 440, 443 (1949) (rejecting government's attempt to introduce defendant's hearsay statements as declarations in furtherance of an implied subsidiary conspiratorial objective of concealing main conspiracy).

There are several reasons, however, why these cases fail to delineate properly the scope of punishable conspiratorial objectives. The trilogy is concerned only with the duration of conspiracies. The rulings do not restrict the state from multiplying a conspiracy's objects for purposes other than extending the statute of limitations. See United States v. Etheridge, 424 F.2d 951, 964 (6th Cir. 1970) (distinguishing Grunewald and Krulewitch because those cases concern only period of conspiracy rather than its separately punishable objects).

These cases, moreover, only limit the state's ability to punish objects that are corollary to the main purpose or purposes of the conspiracy. As the most recent of the three decisions makes clear, the restrictions of the trilogy do not apply to "acts of concealment done in furtherance of the main criminal objectives of the conspiracy." Grunewald, 353 U.S. at 405 (emphasis in original).

Most importantly, the trilogy fails to limit the government's power to punish conditional objects when an act of agreement and an overt act in furtherance of the object can be proven by direct evidence. Even if they are proved to have been agreed-upon, however, conditional plans are not justifiable bases for punishment unless their fulfillment is shown to have been likely or perceived as likely at the time of the agreement. See infra pp. 905-06.

42. 285 F.2d 408 (2d Cir. 1960).

43. Id. at $414-15$.

44. Id. at 416 .

45. The government showed, for example, that several members of the gathering had been previously investigated by grand juries, id. at $416 \mathrm{n} .23$, that some members were currently involved in a special grand jury investigation, $i d$. at $410 \mathrm{n} .2$, that Treasury Department agents had recorded license numbers of cars parked outside the meeting house, $i d$. at 412 , and that each of the defendants was stopped at a police roadblock on the road leading to the meeting house and questioned about his presence in the area, id. at 413. 
of the functions of conspiracy law: preventing likely crimes and apprehending those with a clear expectation of committing a crime.

\section{G. The Limits of the Model Penal Code}

The Model Penal Code does not resolve the confusion of current law. The Code expands a conspiracy's scope to embrace every act contemplated in an agreement-however conditional. On the other hand, the Code excludes from an agreement's objectives any consequences that are not actually desired by the conspirators, even if those consequences are inevitable.

According to the Code, a conditional purpose will suffice as an element of any crime requiring purpose, ${ }^{46}$ unless the condition would render the act a legal one. ${ }^{47}$ The Code, therefore, authorizes the punishment of those who agree to act criminally under even the most unlikely circumstances-as when $A$ and $B$ agree to blow up the Capitol if the Nazi Party wins a majority of seats in the next congressional election. Such a pair would face substantial criminal liability even though they pose virtually no threat and hold almost no expectation of ever carrying their object through.

The Model Penal Code's treatment of conditional acts extends criminal liability beyond the limit justified by the rationales for conspiracy law. The Code's treatment of the conditional consequences of an agreed-upon act, on the other hand, does not extend liability to the extent required by those rationales.

The Code's Advisory Notes expressly state that an agreement to blow up a building does not have murder as one of its objects even if the conspirators know that the act will cause the death of the occupants-unless the killing is a conscious purpose of the agreement. ${ }^{48}$ Exonerating conspirators who both have a clear expectation of causing a specific result and present a clear danger of causing that result is inconsistent with the theoretical foundations of a body of law specifically intended to apprehend those who display a dangerous and unambiguous intention of committing a specific crime.

\section{The Need for a Coherent Rule}

Properly isolating a conspiracy's substantive objects is important for a number of reasons. Jurisdiction ${ }^{4 \theta}$ depends on the objectives of a criminal

\footnotetext{
46. Model Penal Code $\$ 2.02(6)$ (Proposed Official Draft 1962).

47. As, for instance, when someone plans to take home the umbrella in the corner on the condition that it is his own. See W. LA FAvE \& A. Scotr, supra note 5, at 200.

48. Model Penal Code $\S 5.03$ comment at 109 (Tent. Draft No. 10, 1960).

49. Courts have been liberal in finding a nexus between a conspiracy's object and an area of federal concern. See, e.g., United States v. Feola, 420 U.S. 671 (1975) (knowledge that assault victims
} 
agreement, as does punishment. ${ }^{50}$ Moreover, a conspiracy's object determines which actions and statements by the conspirators will be relevant for tolling the statute of limitations, ${ }^{\mathbf{5 1}}$ assessing vicarious liability for the crimes of co-conspirators, ${ }^{\mathbf{6 2}}$ establishing venue, ${ }^{53}$ and admitting hearsay into evidence at trial. ${ }^{54}$

were federal agents not required for conviction of federal crime of conspiring to assault government officers); United States v. Giordano, 693 F.2d 245 (2nd Cir. 1982) (reversing dismissal of charge of conspiring to destroy entity used in interstate commerce even though store that defendants agreed to blow up was invention of undercover officer); United States v. Janotti, 673 F.2d 578, 592 (3rd Cir. 1982) (when Abscam targets agreed "to do acts which, had they been attainable, would have affected commerce. ... [then] regardless of whether an actual effect on commerce was 'reasonably probable,' a sufficient federal interest was implicated to support federal jurisdiction over that agreement"), cert. denied, 457 U.S. 1106 (1982).

This liberality, in conjunction with an expansive interpretation of a conspiracy's object dimension, raises serious concerns about the scope of federal conspiracy jurisdiction. These concerns are all the more compelling in light of significant federal reliance on conspiracy statutes. See Selz, Conspiracy Law in Theory and in Practice: Federal Conspiracy Prosecutions in Chicago, 5 AM. J. CRIM. L. 35, 40-49 (1977) (empirical study citing frequent federal use of conspiracy charge).

50. The central conspiracy provision of the U.S. Code-18 U.S.C. \$ 371-ties a conspiracy's punishment to its object. If the object crime is a misdemeanor, the punishment for the conspiracy may not exceed that allowed for the misdemeanor itself. If the object crime is not a misdemeanor, the conspirators may be sanctioned by a fine of up to $\$ 10,000$ and a prison term of up to five years or both. 18 U.S.C. $\$ 371$ (1982).

Moreover, the conspiracy's object may place the agreement within the punishable scope of a section of the Code other than 18 U.S.C. $\$ 371$. See, e.g., 18 U.S.C. $\$ 372$ (1982) (authorizing \$5,000 fine and six-year prison term for conspiring to injure federal officer); 18 U.S.C. \$ 794 (1982) (authorizing death penalty for conspiring to transmit defense information to foreign government); 18 U.S.C. $\$ 894$ (1982) (authorizing $\$ 10,000$ fine and twenty-year prison term for conspiring to extort money).

If the multiple objects of a single agreement entail violations of different conspiracy statutes, the conspirators may receive cumulative sentences for the different violations. See, e.g., Albernaz v. United States, 450 U.S. 333 (1981) (affirming consecutive sentences for single agreement to import and distribute marijuana in violation of 21 U.S.C. $\$ \$ 846 \& 963$ (1982)).

There is, moreover, a growing movement among state jurisdictions to determine conspiracy punishments according to an agreement's substantive objectives. See Note, Conspiracy: Statutory Reform Since the Model Penal Code, 75 Colum. L. REv. 1122, 1184 (1975) (almost all jurisdictions making criminal law revisions since promulgation of Model Penal Code adopted penalties for conspiracy more closely aligned with those authorized for commission of the substantive crime contemplated).

51. See, e.g., Grunewald v. United States, 353 U.S. 391, 396-97 (1957) (determining scope of conspiratorial agreement "crucial" to resolving questions concerning statute of limitations); McDonald v. United States, 89 F.2d 128, 133 (8th Cir. 1937) ("[C|riminal conspiracy once formed continues until the object of it has been accomplished unless abandoned short of an overt act, or broken up by arrest of the participants."), cert. denied, 301 U.S. 697 (1937).

52. See Pinkerton v. United States, 328 U.S. 640, 645-48 (1946) (conspirator's liability for substantive crimes committed by his co-conspirators depends on whether crimes were committed in furtherance of the conspiracy); United States v. Woods, 544 F.2d 242, 264 (6th Cir. 1976) (by joining conspiracy, defendants become liable for substantive crimes their co-conspirators committed in furtherance of conspiracy), cert. denied, 429 U.S. 1062 (1977).

53. See Hyde v. United States, 225 U.S. 347, 357-64 (1912) (federal conspiracy may be tried either in district in which unlawful agreement made or in any district in which any conspirator committed any overt act in furtherance of conspiracy's object); United States v. Strickland, 493 F.2d 182 (5th Cir. 1974) (venue in conspiracy case may be laid in district where overt acts in furtherance of conspiracy's objectives took place), cert. dismissed, 419 U.S. 801 (1974).

54. See Krulewitch v. United States, 336 U.S. 440, 443 (1949) (hearsay statement of defendant's alleged co-conspirator is admissible against defendant if made during pendancy of conspiracy and in furtherance of its objects); FED. R. Evid. 801(d)(2)(E) (statement not hearsay if offered against party and is made "by a co-conspirator of a party during the course and in furtherance of the conspiracy"). 


\section{Conditional Objectives of Conspiracies}

In addition to expanding the criminal exposure of individual conspirators, the current confusion in the federal law exacerbates the susceptibility of conspiracies to arbitrary or discriminatory enforcement. ${ }^{55}$ This raises concerns that are particularly troubling in light of the historic misuse of conspiracy prosecutions against politically unpopular groups ${ }^{56}$ such as pacifists, ${ }^{57}$ labor organizers, ${ }^{58}$ and communists. ${ }^{59}$

\section{iII. Tailoring a Rule to the Purposes of Conspiracy Law}

\section{A. Likely Crimes, Clear Expectations}

The justifications for conspiracy law are twofold: to allow the state to prevent the execution of crimes whose likelihood of occurrence has grown great $^{60}$ and to allow the state to apprehend conspirators who have revealed a clear expectation of committing specific crimes. In light of the liberty interests underlying the act requirement, ${ }^{61}$ however, conspiracy law should not be interpreted so broadly that the exception to the requirement swallows the rule. Civil liberties and the security interests of the state are best reconciled by defining the scope of conspiracies to include only those objects that are likely to occur (likely crimes) or that are believed by a conspirator to be likely to occur (clear expectations).

In accord with the goal of preventing likely crimes, a conspiracy's punishable scope should embrace those objectives whose fulfillment depends on likely circumstances. The need to prevent dangerously probable crimes does not justify the arrest and punishment of those who have agreed to act criminally or to execute specific criminal results only in response to unlikely conditions. In such situations, the unlikelihood of the triggering

55. Principled and uniform application of the conspiracy laws to individual cases becomes impossible when neither the prosecutor, the judge, nor the jury can say with certainty how far the object dimension of the crime ought to extend.

56. For a general discussion of the use of conspiracy law to deter individuals from joining controversial political causes and groups, see Note, Conspiracy and the First Amendment, 79 YALE L.J. 872 (1970).

57. See Schenck v. United States, 249 U.S. 47 (1919) (denying constitutional challenge of opponents to American involvement in World War I convicted of conspiring to cause insubordination in armed forces by distributing anti-draft literature).

58. For a discussion of the use of conspiracy prosecutions against labor activists, see Sayre, supra note 16 , at $413-16$.

59. See Dennis v. United States, 341 U.S. 494 (1951) (upholding constitutional challenge to conviction of leader of Communist Party for conspiring to advocate violent overthrow of government).

60. The legitimacy of such a goal is well established by the law of attempts. See Bell v. State, 118 Ga. App. 291, 163 S.E.2d 323, (1968) (act of bringing dynamite to building sufficient for conviction for attempt to destroy premises because police must be allowed to prevent crime whose commission would jeopardize safety of people and property); see also W. LA FAVE \& A. ScoTT, supra note 9, at 426 ("IO]ne important function served by the crime of attempt is to provide a basis whereby law enforcement officers may intervene in time to prevent a completed crime.").

61. See supra pp. 896-97. 
events itself vitiates any increased risk of the commission of the conditioned objective flowing from the act of agreement among the conspirators.

The goal of apprehending likely criminals is, on the other hand, not served if conspirators never genuinely expect to fulfill their agreement. If the commission of a crime is conditioned upon the occurrence of an event or the existence of circumstances that a conspirator believes to be unlikely, his attitude toward that crime may never have developed beyond the type of idle speculation or ambiguous hesitancy properly shielded from liability by the act requirement. The clear expectation rationale for dispensing with the act requirement, therefore, justifies punishing conditional objects only when they are premised on events that a conspirator subjectively thinks are likely to occur.

Since these two justifications for the crime of conspiracy operate independently, a conditional intention is a proper basis for punishment if it satisfies either standard. ${ }^{62}$ The principles underlying the act requirement, however, should make the fulfillment of one standard or the other a prerequisite for conspiracy prosecution. ${ }^{63} \mathrm{~A}$ substantive object of a conspiracy thus should be legally cognizable only if the events on which its fulfillment depends are likely to occur or are subjectively believed by a conspirator to be likely to occur. ${ }^{64}$

62. If a subjective belief that conditional events are unlikely discredits the seriousness of an agreement to act in response to those events, a question then arises: Why should such subjective doubt not also undercut the likely crime justification for punishing conspiracies?

The answer stems from the basis for government action in each situation. Under the clear expectation standard, liability is based solely on the genuineness of the offender's subjective intentions. The justification for this liability vanishes whenever this genuineness is not perceived to exist. Under the likely crime standard, liability is based on the danger that a specifically contemplated crime will be carried out. The justification for this liability continues as long as this danger persists.

A mistaken belief that conditional events will not occur undermines the genuineness of a conspirator's subjective intentions. It does not, however, remove the danger that the crime will be committed. If the triggering events in fact occur, a conspirator may be coerced by circumstances into fulfilling his promise or the crime may take place even without his aid. The objective likelihood that conditional events will come about, therefore, is sufficient grounds for liability under the likely crime standard even when that likelihood is not fully appreciated by the conspirators themselves.

63. Conspirators who possess some control over a triggering event and plan to manipulate the event's occurrence seem to be taking a special affirmative step toward the execution of the conditional object-as when conspirators agree to rob a bank if they can obtain a machine gun, and then set about trying to procure one. It is appealing to create a separate standard of liability for such offenders.

If, however, the conspirators possess, or merely think that they possess, enough control over the event actually to cause its occurrence, then their plan to exercise that control would expose them to liability under the clear expectation standard.

An independent basis of guilt stemming from conspirators' plans to exercise control over events, therefore, would be useful only when those plans were unlikely to succeed and were so recognized by the conspirators. Offenders of this type would lack a clear expectation of carrying out their substantive object, and their object would correspondingly lack a dangerous likelihood of commission. There is, therefore, no compelling justification for prosecuting such offenders at the early stage now authorized by conspiracy law.

64. Adapting this rule to a bilateral theory of conspiracy would require either objective likelihood or a shared belief in that likelihood by at least two members of a conspiracy. This modification stems from the requirement, under the bilateral theory of conspiracy, of a meeting of the minds concerning 


\section{Conditional Objectives of Conspiracies}

the essential nature of the conspiratorial plan. See, e.g., Krulewitch v. United States, 336 U.S. 440 , 447-448 (1949) (Jackson, J, concurring) (crime of conspiracy consists primarily of meeting of minds); United States v. Rosenblatt, 554 F.2d 36, 38 (2d Cir. 1977) (conspiracy law requires agreement as to object and "essential nature" of conspiratorial plan); see also Sears v. United States, 343 F.2d 139, 142 (5th Cir. 1965) (no conspiracy would exist with informant who actually intended to thwart conspiracy). Such a meeting of the minds would be absent if one member of the conspiracy believed that his agreement would be ineffectual and the other believed that it would culminate in the commission of a substantive criminal act.

A bilateral theory of conspiracy and the rigid standard of mutuality that it demands, however, are inconsistent with the recognition of an independent rationale for conspiracy law based on a conspirator's firm expectation of committing a crime. As one commentator who strongly supports the bilateral approach points out, that approach recognizes only a likely crime justification for conspiracy law. See P. Marcus, supra note $2, \S 2.04$ at $2-18$ ("[T]he reason the conspiracy offense can be punished wholly apart from the substantive offense, is that conspirators acting together are dangerous .... With the unilateral approach, however, this grave risk will likely be lessened considerably, or actually wholly eliminated. Under such circumstances the rationale for the crime is destroyed, for there is no group danger.") (footnotes omitted).

By concentrating solely on the likely crime justification for conspiracy law, a bilateral theory fails to explain why the crime has traditionally been used to prosecute groups who are neither likely to execute nor even capable of executing their plans. See, e.g., United States v. Waldron, 590 F.2d 33 (1st Cir. 1979) (affirming conviction for conspiracy to transport stolen goods worth at least $\$ 5,000$, even though, unknown to defendants, property transported was worth less than $\$ 5,000)$, cert. denied, 441 U.S. 934 (1979); United States v. Thompson, 493 F.2d 305, 310 (9th Cir. 1974) (to obtain conviction for conspiracy to import marijuana, prosecution need not prove that substance actually smuggled was marijuana), cert. denied, 419 U.S. 834 (1974); Craven v. United States, 22 F.2d 605 (1st Cir. 1927) (defendants guilty of conspiring to violate importation laws by attempting to smuggle domestic liquor), cert. denied, 276 U.S. 627 (1928).

This inconsistency disappears under a unilateral theory of the crime, which recognizes an independent justification for conspiracy law as a means of apprehending those who have revealed a clear expectation of commiting a crime. See MOdel. PeNAL Code $\$ 5.03(1)$ comment at 104-05 (Tent. Draft No. 10, 1960) (advocating unilateral theory of conspiracy because major basis of conspiratorial liability is firm purpose of an individual to commit a crime). Professor Fridman also argues for a unilateral conspiracy law on this basis:

The fact that, unknown to a man who wished to enter a conspiracy to commit some criminal purpose, the other person has no intention of fulfilling that purpose ought to be irrelevant as the first man does intend to fulfill it if he can. . . .

... [A] man who believes he is conspiring to commit a crime and wishes to conspire to commit a crime has a guilty mind and has done all in his power to plot the commission of an unlawful purpose.

Fridman, Mens Rea in Conspiracy, 19 MoD. L. REv. 276, 282-83 (1956).

This movement toward a unilateral theory of the crime is the modern trend in conspiracy law. A number of recently revised statutes now follow the Model Penal Code in punishing whoever agrees to commit a crime without regard to the actual intentions of his co-conspirators. See Burgman, Unilateral Conspiracy: Three Critical Perspectives, 29 DE PAuL L. REv. 75, 75 n.3 (1979) (criticizing unilateral conspiracy law but listing 30 states that have adopted statutes conforming to Model Penal Code's unilateral approach).

In keeping with the clear expectation justification for conspiracy law, the law should punish any conspirator who believes that triggering events or circumstances will come about and enters into an agreement with another who he thinks shares his beliefs (regardless of the actual thoughts of his coconspirator). Such a conspirator has crossed a clear psychological threshold regarding his future criminal conduct. For the reasons already listed, however, this same rationale does not justify punishing the doubting co-conspirator if the triggering events are themselves unlikely. This should be true even in jurisdictions which now observe a bilateral theory of conspiracy. To hold otherwise is to preserve a needless tension in the law and to curtail the usefulness of the conspiracy offense. 


\section{B. The Effect of the Rule}

Adoption of this rule would remedy the current confusion of the federal law. Conspirators such as the defendants in Feola ${ }^{65}$ and Etheridge ${ }^{68}$ would not be liable for criminal objects which they did not expect to commit and were not likely to commit when they made their agreement. On the other hand, conspirators such as the Bufalino ${ }^{67}$ defendants would face liability for the likely and expected results of their agreements.

The standard set out above would also resolve the inconsistencies of the Model Penal Code. ${ }^{68}$ Likely consequences of an agreement would be punishable whether they were desired by the conspirators or not. Unlikely and unexpected conditional objects, on the other hand, would not warrant prosecution even if the conspirators specifically agreed to commit them.

\section{ConCLuSION}

Because it provides prosecutors with substantive and procedural advantages with a proven history of abuse, conspiracy is a crime " to be narrowly watched, to be jealously regarded, and never to be pressed beyond its true limits." "69 By limiting punishment to objects that were objectively likely to occur or were believed by a conspirator to be likely to occur, the rule advocated in this Note would confine the use of conspiracy prosecutions to the justifiable goals of preventing likely crimes and apprehending likely criminals.

-Patrick A. Broderick

65. United States v. Feola, 420 U.S. 671 (1975). See supra pp. 897-98.

66. United States v. Etheridge, 424 F.2d 951 (6th Cir. 1970), cert. denied, 400 U.S. 993 (1971). See supra pp. 898-99.

67. United States v. Bufalino, 285 F. 2 d 408 (2d Cir. 1960). See supra p. 900.

68. See supra pp. 900-01.

69. J. TuRner, Kenny's Outlines of Criminal Law II 452 (19th ed. 1966) (quoting Fitzgerald, $\mathrm{J}$. in the Irish State Trials of 1867). 